\title{
Obstacles in establishing and operating a public sector internal auditing function in a developing country: The South African experience
}

\author{
D B van der Schyf \\ Department of Accounting and Finance \\ University of Pretoria
}

\begin{abstract}
The point of exit in this research is that there should be an internal audit department in a national government department in South Africa to render a top-class internal auditing service that is cost-effective and affordable, preferred by clients, continuously complies with the standards of professional practice of internal auditing and best practice and have a positive impact on the national government department's bottom line. The empirical research has highlighted several factors, including the ignorance of key role players and lack of professional proficiency on the part of internal auditors, as factors that impede the establishment and operation of an internal auditing function in the public sector in South Africa. It is recommended, that audit committees in the public sector should launch a joint marketing action, directed at key role players, to promote the potential value of a top-class internal auditing service in the public sector, as well as the factors that impede it.

Key words

Audit committee

Internal audit service

Internal audit departments

National government departments

Internal auditing

Public sector

Internal auditors
\end{abstract}




\section{Introduction}

The purpose of this study is to share with other countries, specifically other developing countries and, in particular those countries that envisage the establishment, or are establishing, an internal auditing function in the public sector, the South African experience with regard to the establishment and operation of the internal auditing function in the public sector. A secondary goal is to share the research findings with interested parties in the public sector in South Africa. The motto of The Institute of Internal Auditors "Progress through sharing", served as an encouragement for the study.

Unfortunately, no comparable study was identified in the literature review for this study.

Against the background of the modern view of the internal auditing function and the fact that the internal auditing profession, represented by the Institute of Internal Auditors Inc, will be sixty years old in 2001, the following opinion, expressed by Arthur Hald in 1944 is indeed prophetic in respect of the internal auditing function in the public sector:

"Necessity created internal auditing and is making it an integral part of modern business. No large business can escape it. If they haven't got it now, they will have to have it sooner or later and, if events keep developing as they do at present they will have to have it sooner." (Hald 1944)

Modern internal auditing began to evolve in 1941 when The Institute of Internal Auditors was formed. Only then did internal auditors expand the scope of internal auditing to the appraisal of all operations of the enterprise. Only then did internal auditors stand up as equals to their external counterparts (Sawyer et al 1996:10). The private sector and various governmental agencies throughout the world have played a prominent role in the movement toward the modernization of internal auditing procedures. The United States and various other countries have played a major part in broadening the role of the internal auditor in the government environment (Flesher 1996:15).

Today the overriding purpose of internal auditing is to provide management with a continual, independent and objective view of the business operations, with the main focus on risk management, control systems, performance and corporate governance.

The exact nature and extent of modern internal auditing is concisely and strikingly contained in the new definition that was formally adopted by The Institute of Internal Auditors Inc in 1999, namely (Update 1999): 
"Internal auditing is an independent, objective assurance and consulting activity designed to add value and improve an organisation's operations. It helps an organisation accomplish its objectives by bringing a systematic, disciplined approach to evaluate and improve the effectiveness of risk management, control, and governance processes."

The new definition, which is already the norm against which the modern internal auditing function in the public sector in the USA and other leading countries is being measured, together with the internal auditing standards of The Institute of Internal Auditors Inc., was also used in this study. It is the benchmark against which an appropriately utilised internal auditing function in the South African Public sector should also be evaluated. This internal auditing function was given new status by the Public Finance Management Act (Act 1 of 1999 as amended by the Public Finance Management Amendment Act (Act 29 of 1999)), which introduced a new era of modern management, leaning heavily on internal auditing as a management tool to ensure healthy financial management at all levels of the South African public sector.

In order to appropriately assess the contributory role that the Public Finance Management Act fulfils in getting the internal auditing function properly established in the public sector, a brief historical overview of the development of the internal auditing function in the public sector is presented below.

\section{Development of the internal auditing function in the South African public sector: An historical overview}

Before the internal auditing function in the public sector in South Africa was given its official name in the early nineties, it consisted mainly of internal control and inspection components. Efforts centered around financial and logistic inspection as well as compliance auditing. Valuable inputs in terms of ensuring compliance with laws, regulations, policies and instructions were obtained in this manner, but there were some general shortcomings, the most prominent of which are listed below:

- There were no specific initiatives to test and evaluate internal controls;

- components relied on the third checking function of internal control/inspection sections, reducing their own effectiveness within the department; and

- outputs and systems were not evaluated,

All of these shortcomings considerably minimised the contribution of the function of internal auditing as a management tool.

Meditari Accountancy Research Vol. 8 2000: 145-181 
The financial regulations promulgated in terms of the Exchequer Act (Act 66 of 1975), augmented by way of Government Gazette No 5791, dated 1 November 1996, made it the responsibility of accounting officers to establish an effective internal audit department and audit committee. Indeed, it was on this occasion that the internal auditing function in the public sector was given official and statutory status. The expectation was created that the internal auditing function in the public sector had to move away from the traditional role of monitoring compliance with policies and procedures and reviewing financial controls, towards the modern expectation of being able to respond as a management tool to organisational and managerial needs.

In 1996, momentum for the new status of the internal auditing function in the public sector in South Africa came from three sources:

1. The Regulations Concerning Public Entities which came into force on 7 May 1993, and is an extension of the Reporting by Public Entities Act, 1992 (Act 93 of 1992), for the first time made statutory mention of the Institute of Internal Auditors by requiring that the internal auditing function of public entities should function in accordance with the internal auditing standards of the Institute. In the Regulations Concerning Public Entities (published in Government Gazette No. 5076, dated 7 May 1993), which is supplementary to the Act, the board of each entity is obliged to establish, inter alia, an audit committee, and an internal auditing function. Although the entities are semi-state institutions, the act made an important contribution in preparing the ground for statutory regulations for the establishment of the internal auditing function in the public sector.

2. Momentum for the new status that the internal auditing function in the public sector had been given in 1996 also came from the issuing of the so-called King Report (The Institute of Directors in Southern Africa, 1994) on corporate governance in South Africa. This report recommends inter alia that all listed companies in South Africa should have an effective internal audit division at their disposal. This 
recommendation, which was made at the end of 1994, almost immediately created a greater awareness of the internal auditing function in the private and public sectors in South Africa. The recommendations regarding the internal auditing function in the King Report are also clearly present in the provisions in Government Gazette No. 5791 of 1 November 1996, in which accounting officers are charged with the responsibility of establishing an effective internal audit department and an audit committee.

3. Finally, the newly found status of the internal auditing function in 1996 can also be relayed to the contributory role which the Auditor-General Act (Act 12 of 1995) played in the development of the internal auditing function. According to section 3(4) (a) - (d), the Auditor-General, as the independent external auditor of the public sector departments, shall reasonably satisfy himself or herself that:

- Appropriate precautions have been taken to safeguard the proper collection of money and that the laws and instructions relating thereto have been duly observed;

- reasonable precautions have been taken in connection with the receipt, custody and issue of, and accounting for, property, money. stamps, securities, equipment, stores, trust money, trust property and other assets;

- $\quad$ receipts, payments and other transactions are made in accordance with the applicable laws and instructions and are supported by adequate vouchers; and that

- $\quad$ satisfactory management measures have been taken to ensure that resources are procured economically and utilised efficiently and effectively.

When reporting, the Auditor General shall, in particular, mention where, in his or her opinion, the applicable internal control and management measures are inefficient or ineffective.

The focus of internal auditing clearly covers the same terrain, but from an internal perspective. The degree of overlap is obvious. However the statutory duties of the Auditor General in this regard have become the selfevident responsibility of the internal auditor which has also been regulated statutorily.

The historical course of the development of the internal auditing function in the public sector was finally concluded with the provisions on the 
internal auditing function as contained in the Public Finance Management Act (Act 1 of 1999 as amended by the Public Finance Management Amendment Act (Act 29 of 1999)) and the Treasury Regulations for departments and constitutional institutions issued in terms of the Public Finance Management Act, 1999 (Regulation Gazette No 6822 dated 31 May 2000). Section 38 of the Public Finance Management Act makes it the duty of the accounting officer to ensure that a national government department has at its disposal inter alia an internal auditing function, while Section 76 of the Act requires that National Treasury Regulations must promulgate what the audit committee and the internal auditing function will regulate inter alia in the national government departments. Section 3 of the Treasury Regulations provides more detailed provisions on the functioning of the audit committee and the internal auditing function in the public sector in South Africa.

The Public Finance Management Act (Act 1 of 1999 and the Amendment Act (Act 29 of 1999)) as well as the Treasury Regulations (Regulation Gazette No. 6822, dated 31 May 2000) enabled the establishment and operation of a modern internal auditing function in the public sector in South Africa. The question arises as to whether all factors are favourable for establishing and operating an internal auditing function in the public sector, considering the favourable support that legislation and regulations can lend to it.

Finally a typical organogram of a national government department, within which the audit committee and the internal auditing function operate within the new legislation is proffered. Although the term "organogram" is not generally used in the private sector, it is well known in the South African public sector. Operationally the audit committee reports directly to the Director General, while the internal auditing function reports through the ordinary operational channels to the Director General and communicates functionally with the audit committee.

In the discussion of the research findings, this organogram is again referred to 


\section{Figure 1}

Typical organogram of a national government department

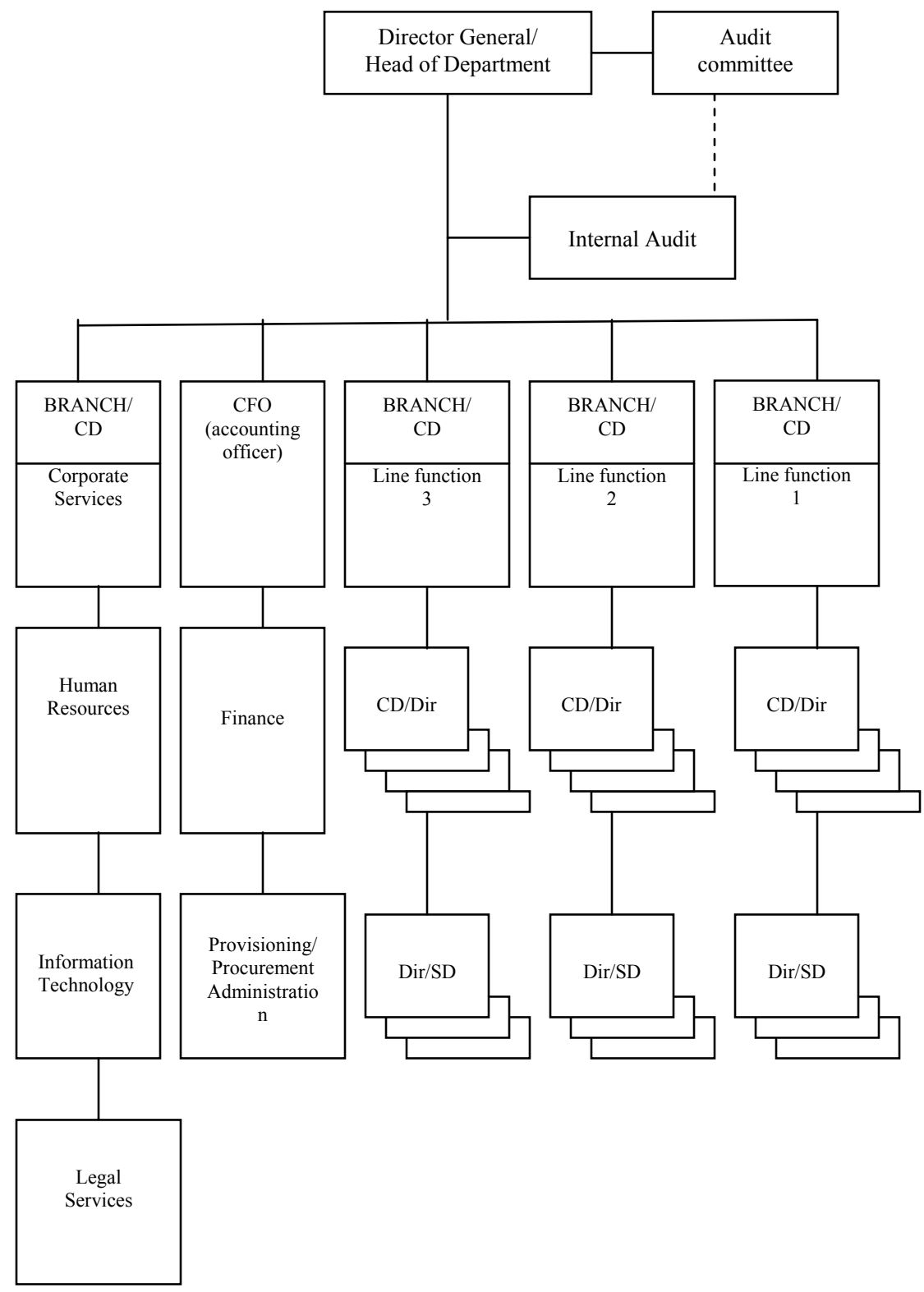




$\begin{array}{lll}\text { Legend: DG } & - & \text { Director General } \\ \text { HOD } & - & \text { Head of Department } \\ \text { CD } & - & \text { Chief Director } \\ \text { CFO } & - & \text { Chief Financial Officer } \\ \text { Dir } & - & \text { Director } \\ \text { SD } & - & \text { Subdirectorate }\end{array}$

The internal auditing function in the South African public sector, as in virtually all countries of the world, is the product of public policy and legislation. Public policy processes are often praised for their strength of vision, but criticised for being weak in implementation. Where the obstacles in the establishment and operation of the public sector internal auditing function will come under scrutiny in this project, the focus will of necessity also fall on legislation, policy and principles which support the internal auditing function in this specific area.

The research methodology used in this research report to gather information is discussed hereafter.

\section{$3 \quad$ Research Methodology}

\subsection{Introduction}

The research report comprises a literature study and an empirical study.

\subsection{Literature study}

The internal auditing profession worldwide is relatively young. The Institute of Internal Auditors was established in 1941 in the United States, and that is why the internal auditing function, as a professional function, is also relatively young. The literature study revealed that the United States and other countries, including Canada, already played a significant role in extending the internal auditing function in the public sector of the respective countries a few decades ago.

The new definition of internal auditing quoted above represents a thorough description of the modern internal auditing function. It also emphasises the value thereof as a very useful management tool to improve risk management, control systems, business performance and corporate governance.

This modern internal auditing function, which is already well established in the public sector in leading countries also functions as a norm in this research report for the operation of the internal auditing function in the public sector in South Africa. 
The Institute of Internal Auditors in South Africa was only founded in 1983. Active co-operation between the Institute and internal auditors in the public sector only became visible in 1997. In 1998 the Internal Audit Forum was founded as a forum on which the heads of internal audit departments in the entire public sector (also provincial), meet regularly to discuss current issues and modern internal auditing practice. The sustained prominence and contributions of The Institute of Internal Auditors in South Africa at the Internal Audit Forum boosted the awareness of the value and status of the modern internal auditing function and the internal auditing profession amongst internal auditors in the public sector in South Africa.

The above also explains why the literature study on the development of the internal auditing function in the public sector in this research project focuses on the contributions of specific legislation.

Unfortunately no comparable study was available to support the literature review.

Finally, it may rightly be said that the development of the internal auditing function in the public sector in South Africa, which was initially characterised as a control and inspectorate function, operated mainly in terms of policy, procedures and legislation and in virtual isolation from internal auditing in the private sector.

\subsection{Empirical study and target group}

This research project and its title are the result of presentations made and discussions that took place from 1998 to September 2000 on the Internal Audit Forum. The forum takes place regularly and is arranged by the Institute for Public Finance and Auditing (IPFA) as a service to its members. The members of the Forum include heads of internal audit departments in the public sector (including the nine provinces), a representative of the Auditor General, the Executive Director of the Institute of Internal Auditors in South Africa, a representative of the universities, a representative of the technikons, internal audit consultants and representatives of the Big Five Public Sector Accountants and Auditors firms, that render internal auditing services in the Public Sector.

Guidelines for the focal points of the research project followed after interviews were conducted with experienced heads of internal audit departments in the public sector. From presentations made and discussions held at the Internal Audit Forum as well as from interviews with experienced heads of internal audit departments it was clear that stumbling blocks had been experienced in respect of the establishment and operation 
of the internal auditing function. Nearly all the internal auditing functions in the public sector were established between 1995 and 2000 as distinct from the control and inspectorate functions. The greater majority of such departments were established only two to three years ago.

Because the thirty-four national government departments may be seen as a homogeneous group for the purposes of this research, the internal auditing function of the provincial governments were excluded from the research. The target group of thirty-four was reduced to thirty-two because two national government departments do not have an internal auditing function.

A questionnaire was used for data-gathering. The questionnaire comprised statements only, which were divided into two groups, viz. section A: Obstacles experienced in establishing the internal auditing function in the South African public sector; and Section B: Obstacles experienced in operating the internal auditing function in the South African public sector.

The statements were based on information obtained from the following sources:

a. Discussions which took place at the Audit Forum;

b. interviews conducted with internal auditing heads in the public sector; and

c. literature, including also statutory rules and regulations, which regulate the internal auditing function in the public sector.

From the information gathered, factors were identified which could either have impeded the establishment of the internal auditing function, or could have prevented the operating thereof in the public sector, or could have been an obstacle to both. The questionnaire was given to heads of internal audit departments in October 2000. They had to decide whether they agreed with the statements under Section A in the questionnaire, Obstacles Experienced in Establishing the Internal Auditing Function, comprised thirty-five statements. Heads of internal audit had to decide whether they agreed with each statement. The same request was made in respect of Section B, Obstacles Experienced In Operating the Internal Auditing Function, comprising thirty-two statements. Because certain factors can impede the establishment and operation of the internal audit function, there is a reasonable overlap in the statements in section A and in section B. The statements in both divisions can be divided into six categories, namely:

Independence of the internal auditor, the poor image of the internal auditing function, inability of management to exploit the usefulness of the internal auditing function, audit staff issues, lack of a professional attitude 
on the part of internal auditors and the lack of exploitation of the value of the audit committee.

Respondents were assured that the information they provide would be treated with confidentiality and that details of respondents would not be included in the research report. Space was provided in the questionnaire, for respondents to give additional information. Some respondents made use of the opportunity to express an opinion on the statements. In some cases, the opinions were quoted to substantiate conclusions.

Respondents were requested to complete the questionnaire only if the department had an internal auditing function. If the internal auditing function was outsourced, or co-sourced, only this fact was to be mentioned and the questionnaire returned.

Of the 32 questionnaires distributed, 21 were returned. The response rate of $65,6 \%$ may be considered to be extremely satisfactory for the public sector, particularly if it is taken into consideration that a few heads of internal audit departments stated beforehand that they felt threatened by the ultimate disclosure of the research findings. The responses indicate that 19 departments had an internal auditing function, while in two departments the function was outsourced. The analysis of the responses therefore relates to 19 national government departments.

\section{Analysis of the responses}

\subsection{Introduction}

The responses to the statements are discussed in terms of the six categories used in the questionnaire. The discussion is made under the headings, "Obstacles in establishing the internal auditing function in the public sector" and "Obstacles in operating the internal auditing in the public sector". In the conclusions on the statements under each of the six categories, the opinions given by heads of internal audit departments, are also taken into consideration. The new definition of internal auditing and applicable auditing standards form the frame of reference against which the internal auditing function in the public sector is evaluated.

\subsection{Obstacles in establishing the internal auditing function in the South African public sector}

An overwhelming number of respondents (72,3\%) supported the statements that implied that there were obstacles in the establishment of the internal auditing function. The reactions of the respondents are as follows:

\subsubsection{Independence of the internal auditor}


The new definition of internal auditing emphasises that internal auditing is an independent, objective assurance and consulting activity. The first internal auditing standard "independence" sets the requirement that the two specific standards, objective and organisational, should support independence in good internal auditing practice.

The greater majority of respondents, namely $75,4 \%$, were of the opinion that independence of the internal auditing function could be seen as a stumbling block in the initial establishment of the internal auditing function.

The statement that implies that Directors General initially wanted to prescribe to internal auditors regarding what had to be audited, and were therefore perceived as a threat to independence, was rejected by $57,9 \%$ of the respondents. Finally, as far as the independence of the internal auditing function in the public sector is concerned, two respondents stated in writing that the implementation and functioning of the audit committee conspicuously promoted the independence of the internal auditing function in the relevant national government departments.

\subsubsection{The poor image of the internal auditing function}

A large majority of respondents $(81,5 \%)$ were of the opinion that the poor image of the internal auditing function in the public sector had a detrimental effect on the establishment of the function. The following factors, which appeared in the statements in the questionnaire and could have contributed to the unfavourable image of the function, enjoyed support:

- Confusion of the internal auditing function with the previous "inspectorate" function;

- the internal auditing function was perceived to overlap with the external auditing function (Auditor General); 
- the image of internal auditors was not sufficiently promoted in the public sector;

- the image of the function was affected detrimentally by the Head of Internal Audit being placed at a low a post level (below director - refer to the organogram of a national government department - some suggested it should be above that of a director);

- lack of resources (funds) to establish and promote the internal auditing function effectively, and

- the internal auditing function in the public sector did not have a benchmark against which performance could be measured.

The only negative reaction to the image of the internal auditing function was in response to the statement: "The Head of Internal Audit does not have direct access to the accounting officer". A total of 52,6\% of the respondents did not experience a problem during the establishment of the internal auditing function, to obtain unlimited access to the accounting officer.

As far as accessibility to the accounting officer is concerned, the following interesting and significant remark was made in response to the questionnaire:

"Accounting Officers do not have time to sit with the Head of Internal Audit to discuss the internal auditing activities. They rather focus on operational activities".

Finally, the development of the image of the internal auditing function in the public sector should be viewed with empathy and appreciation. It is unrealistic to expect that it would have a strong image at conception because it developed from an "inspectorate" function and had a strong regulatory and statutory past that left little room for professional exposure.

\subsubsection{Inability of management to exploit the usefulness of the internal auditing function}

The growth in the usefulness of the internal auditing function in the private sector may be directly ascribed to the fact that it is a consulting activity, which adds value and improves an organization's operations. This utilitarian value of the internal auditing function is also visible in the new description thereof.

The purpose of this investigation was also to determine the extent to which the utilitarian value of the internal auditing function, as stated and described, is utilised by management in the public sector. If management had been enthusiastic to utilise the function, it would have facilitated the 
establishment of the internal auditing function. A number of statements in the questionnaire focussed on this aspect and the following factors identified, which serve as basis for the statements. The presence of these factors is an indication that the usefulness of the internal auditing function were not fully exploited by management and, by implication, impeded the establishment of the internal auditing function.

- Ignorance of key role players about the nature and value of the internal auditing function, for example:

- $\quad$ Political head of a national government department (Minister): $63,2 \%$ positive reaction (Minister is ignorant - a negative factor).

- members of SCOPA (Standing Committee on Public Accountants): $63,2 \%$ negative reaction (SCOPA is aware of the value of the function).

- $\quad$ Director General: 52,6\% positive reaction (Director General is ignorant - a negative factor).

- $\quad$ management of the Department: $78,9 \%$ positive reaction (management is ignorant - a very negative factor).

- $\quad$ general staff of national government departments: 84,2\% positive reaction (general staff are ignorant - also a very negative factor).

- The consulting value of internal audit in the public sector not publicised sufficiently.

- The audit charter does not have sufficient support from top management.

- Management numbers do not consistently demonstrate that they understanding the relevant requirements of The Public Finance Management Act regarding the internal auditing function in national government departments.

- Changes of Directors General which give rise to demands for new work relationships, new understanding of the needs, value and role of the internal auditing function.

- The institution of the internal audit function in national government departments only became compulsory as recently as 1995 .

- It was difficult to fulfil the responsibility of the internal audit function in the national government departments to evaluate systems of financial and risk management and internal control, and to make recommendations for the improvement thereof, because the systems were not in operation in all cases. 
- The Financial Information Systems in the public sector were government control systems and not modified to facilitate the requirements of the Public Finance Management Act.

- The accounting officers did not give a high priority to the establishment of an effective internal audit department and audit committee as required by the Exchequer Act, No 66 of 1975 (augmented by Government Gazette No 5791, dated 1 November 1996).

- Before the commencement of the Public Finance Management Act, internal audit reports did not evoke the required response and actions.

The above factors, which formed the basis for statements and prejudiced the utilisation of the internal auditing function as a management tool and, by implication, impeded the establishment of the internal auditing function, enjoyed the support of $67,8 \%$ of the respondents.

The internal auditing function, as perceived in its modern description, has great potential value for the management of national government departments. The challenge is to inform about and convince them of this value. A matter for concern is the view of heads of internal audit of national government departments regarding the fact that the ignorance about the value of the internal auditing function of Political heads of department, Directors General, managers of departments and the general staff was a stumbling block in the implementation of the internal audit function.

In conclusion, the following remarks made by two respondents are relevant:

- "Top management has no time to read and understand the Public Finance Management Act because they are locked-up in meetings all day".

- "The effectiveness of the Internal Audit Component and the benefits to be derived will ultimately depend on the ability of management to use the function effectively, and to respond constructively to findings and recommendations made by it". 


\subsubsection{Audit staff issues as an obstacle}

The statements on this matter were supported by an average of $78,9 \%$ of the respondents. Competent and professionally accomplished internal auditing staff are an essential prerequisite for the successful operation of an internal auditing function. The guidelines on the qualities of professionally accomplished internal auditing staff are set out in General Standard 200 "Professional Proficiency" of the Standards for the Professional Practice of Internal Auditing of the Institute of Internal Auditors Inc (1998:17).

Several factors served as basis for the statements, the typical past of the internal auditing function in the public sector and particular audit staff matters including the following factors should be emphasised:

- There is a lack of experienced internal auditors in national government departments to implement the requirements of the Exchequer Act;

- There is a lack of proper training facilities for internal auditors in the public sector to provide the resources to execute the requirements of the Exchequer Act;

- There is a lack of appropriate academic training programmes at universities and technikons for internal auditors in the public sector;

- Unwanted personnel in other departments were "dumped" in the internal auditing department;

- Availability of properly trained personnel;

- Lack of resources (funds) to create posts and fill vacancies.

Professionally proficient internal auditors are critically important to the operation of an internal audit function in a professional manner in accordance with the auditing standards of The Institute of Internal Auditors. Professionally proficient internal auditors are the members of staff in an audit department who jointly have the required professional proficiency, knowledge and related expertise in subjects such as accounting, management and economics, statistics, to be able to execute a specific internal auditing assignment. If an internal audit department does not have at its disposal all the expertise required for the execution of the relevant internal auditing assignment, staff who do have the skills or knowledge required should be contracted.

Against the background of the above negative factors and the requirements of professional proficiency in the internal auditing standards, it is not surprising that $78,9 \%$ of the respondents identified internal audit staff issues as being an obstacle in the establishment of the internal auditing function. 
Although some of the factors are already receiving attention, the issue of the professional proficiency of the internal auditing corps should enjoy a high priority. Without professionally proficient internal audit staff, an internal audit department in a national government department can not render a professional internal audit service at the highest level. Moreover, such an internal auditing function will barely be able to add value. The question that should be asked, is whether an internal audit department which does not have a professional frame of reference has a right to exist.

\subsubsection{Lack of a professional relationship for internal auditors}

It is very obvious that a group of persons who are members of a professional body will show greater understanding of and dedication to the maintenance of professional standards in service rendering as well as the upholding of ethical norms than a group of non-professional persons. Employers are aware of the level of service rendering and maintenance of standards and ethical norms by professional persons in executing their tasks.

The purpose of the statements in this section of the questionnaire was to determine the awareness of the value and benefits of professional membership of The Institute of Internal Auditors in the internal audit departments and in government departments. The following factors formed the basis of the various statements:

- Internal auditors are not obliged to be members of a professional association. Altogether $63,2 \%$ agreed that this situation prevails in their internal audit departments.

- Too few internal auditors in the public sector are members of The Institute of Internal Auditors in South Africa. The positive response of $63,2 \%$ is very encouraging because it indicates that heads of internal audit departments are aware of the value of professional membership.

- Certain national government departments are not prepared to pay internal auditors' membership fees of IIA (SA). Only $42,1 \%$ of national government departments pay the professional membership on behalf of their audit staff. Although this attitude is discouraging, it is an indication of the lack of awareness of the value of professional membership of members. 
- The highest professional qualification for internal auditors, Certified Internal Auditor (CIA), is unknown in the public sector. A total of $78,9 \%$ of heads of internal audit departments agree with this statement. Although heads of internal audit departments should, with the support of the audit committee, inform their Accounting Officers about the value of a CIA qualification, promotion of the CIA qualification can probably be better achieved by a joint effort of the head of internal audit departments and representatives of the IIA (SA).

If national government departments promoted the professional relationship between internal auditors and the IIA (SA) the improved relationship would be mutually beneficial.

\subsubsection{The value of the audit committee not fully exploited}

The audit committee is generally accepted to be a valuable mechanism in the support of the operation of the internal auditing function. The audit committee is a relatively new concept in the public sector in South Africa. It is confirmed by the fact that internal audit departments on average were established 2-3 years ago and that an audit committee in each department was established shortly thereafter. In view of the specific stumbling blocks experienced in the establishment of the internal auditing function discussed above, the audit committee could not have played a contributory role in the process. Audit committees also experienced the typical problems in their establishment and initial operations. In some cases the problems have not yet been entirely resolved. The placement of and reporting line for an audit committee in a typical national government department is illustrated in the organogram.

The purpose of the statements in this section was to determine how heads of internal audit departments initially experienced the activities of the audit committees. The statements focussed on the factors mentioned below. Responses to the statements could have been influenced by the fact that audit committees were established fairly recently:

- The audit reports of the Auditor General were only able to effectively add value after the audit committee had been established. This statement received 57,9\% support. It should be borne in mind, however, that the opinions of respondents could have been influenced detrimentally by the fact that audit committees are relatively new institutions. 
- The audit committee initially consisted of members of the national government department concerned. This fact was considered to be a constraint on the functioning of the audit committee by $73,7 \%$ of the respondents.

- The audit committee was not being independent, because it reported to the Director General and not directly to the Minister. Only 52,6\% of the respondents agreed with this statement.

The audit committee was discussed under "Independence of the internal auditor" above. It was emphasised in that context that the audit committee could not fulfil its characteristic role of supporting the independence of the internal auditing function in the public sector, because the audit committee itself was still being established.

Finally, the above discussion of the opinions of the heads of internal audit departments in the national government departments, it can be concluded that there were obstacles to the establishment of the internal auditing function in the South African public sector. This hypothesis received overwhelmingly support from respondents who strongly supported the statements as well as the factors on which the statements were based. The statements were presented under the following headings: independence of the internal auditor; poor image of the internal auditing function; inability of top management to exploit the usefulness of the internal auditing function; audit staff issues; lack of a professional relationship; and the value of the audit committee not fully exploited. By implication, respondents also gave their overwhelming support to those aspects upon which the statements focussed. The said aspects are also highlighted in the subsequent section.

\subsection{Obstacles in respect of operating the internal auditing function in the South African public sector}

In the preceding section the emphasis was placed on the establishment of an internal auditing function, while in this section the searchlight falls on the operation of an internal auditing function. There is a definite time difference between the two situations mentioned. Although internal audit departments in the national government departments were established only 2 to 3 years ago, a reasonable period had elapsed since the establishment of the internal auditing functions and the conducting of the research survey, which took place at the beginning of October 2000. The respondents, and by implication their internal audit departments, had had reasonable experience of the operation of the internal auditing function.

The statements on the operation of an internal auditing function were, to a large extent, duplication of statements used regarding the establishment

Meditari Accountancy Research Vol. 8 2000: 145-181 
(Section $\mathrm{A}$ in the questionnaire) of an internal auditing function. The focus is on the same categories, although slightly adapted, viz. independence of the internal auditor; image of the internal audit function; ability of top management to exploit the usefulness of the internal auditing function; audit staff issues; lack of a professional relationship for internal auditors; and the value of the audit committee.

It is therefore to be expected that some of the responses will have a great deal of consensus with the responses analysed in section A.

A large number of respondents $(69,4 \%)$ supported the statements, implying that there were obstacles in the operation of an internal auditing function in the South African public sector. The reactions of respondents are discussed below in terms of the six categories:

\subsubsection{Independence of the internal auditor}

As with the corresponding discussion in section A, the new definition of internal auditing and the internal auditing standards were used as norms in terms of which independence was measured.

A majority of respondents $(57.9 \%)$ were of the opinion that independence, in the operation of an internal auditing function in the public sector in South Africa, could be considered to be a stumbling block.

The following factors formed the basis of the various statements:

- The independence of the internal auditing function in the public sector was accepted with difficulty. A total of $73,7 \%$ of responses supported the statement.

- Directors General want to prescribe what should be audited. Altogether $63,2 \%$ of the respondents did not experience this to be true. Therefore the relevant statement was rejected by $63,2 \%$ of the respondents who were of the opinion that this situation did not pose a threat to the independence of the internal auditor in the operating of the internal auditing function.

- The reporting lines of the internal auditing function threatened the independence of the function. A majority of $63,2 \%$ of the respondents agreed with this statement. This is a serious matter that deserves urgent attention.

The reaction of respondents indicate that the independence of the internal auditor in the internal auditing practice in the public sector is not a foregone conclusion. In fact it deserves urgent attention, also from the audit 
committee, because independence in terms of the definition of internal auditing and internal auditing standards is the critical element in the operation of an internal auditing function.

\subsubsection{Image of the internal auditing function}

A substantial majority of respondents $(70,2 \%)$ were of the opinion that the poor image of the internal auditing function in the public sector has a detrimental effect on the operations of the internal auditing function. The following factors, which contribute to a poor image, were included with the statements:

- A lack of promotion of internal auditing.

- The internal auditing function is relatively new. The establishment of the functions in national government departments only become compulsory in 1995 .

- The internal auditing function in the public sector did not have a benchmark against which performance could be measured.

- The nature and use of the GAIN programme of The Institute of Internal Auditors Inc was not known to heads of internal audit departments in the public sector; the image of the function was prejudiced as a result of the post of head of internal audit being set at a low post level.

- The audit charter did not enforce sufficient authority beyond the internal audit department.

The internal auditing function as it currently operates in the public sector is a recently established function. It is therefore reasonable to expect that it would not yet have a strong image. It developed from an "inspectorate" function fairly recently. Its strong regulatory and statutory past has left little room for professional exposure.

The above factors, upon which the relevant statements were based, should not merely be seen as threats to the image of the internal auditing function, but also as opportunities and challenges for heads of internal audit. Many solutions will depend on the professional manner in which the internal auditing function is executed. Will it be able to add value and improve an organization's operations? If this proves to be the case, a positive image of the function could emerge.

Finally, two remarks from the questionnaire are relevant in this context:

- "The Heads of Internal Audit should make more attempts to assert themselves and sell/market the internal auditing function to their departments", and 
- "Internal audit components need to market their responsibilities to the institutions by presenting information sessions. The head of internal audit should be a member of management meetings in order to add value during strategic planning".

\subsubsection{Ability of top management to exploit the usefulness of the internal auditing function}

The usefulness of the internal auditing function, as described above, is embedded in the fact that it is a consulting activity which adds value and improves an organization's operations. In brief, it provides assurance to clients on matters relating to control, risk management and corporate governance.

The purpose of the research in this category was to determine the extent to which the usefulness can be utilised by management in the public sector. If management is enthusiastic to utilise the function appropriately, it will greatly facilitate the operating of the function. A number of statements in the questionnaire focus on this aspect. That considerations below served as a basis for the statements. The confirmation of the factors would be an indication that the usefulness of the internal auditing function are not fully exploited by management and, as a result, this impedes the operation of the internal auditing function:

- The traditional view of key role players was that the internal audit department should only be concerned with the monitoring of compliance with policy and procedure and reviewing financial controls (supported by $84,2 \%$ of respondents as still being the present view);

- Ignorance of internal auditors (in general in the public sector) about the value of the internal auditing function for the department, namely:

a. to act in a consulting capacity that is designed to add value and improve the department's operations.

b. to assist a department to accomplish its objectives by bringing a systematic, disciplined approach to the evaluate and improve of the effectiveness of risk management, control and governance processes. The fact that $78,9 \%$ of respondents agreed with this statement is a reason for great concern. It is an 
indication of the low level of awareness among internal auditors in the public sector of the particular service that they could offer.

- Changing of Directors General makes the following demands:

a. New work relationship between the new Director General and internal auditing function.

b. New grasp of the needs, values and role of the internal auditing function $(73,7 \%$ respondents agreed with the statement).

- Ignorance of key role-players about the nature and value of the internal auditing function, for example:

- Political head of national government department (Minister): $63,2 \%$ positive reaction (Minister is ignorant - a negative factor).

- Members of SCOPA (Standing Committee on Public Accountants): $68,4 \%$ negative reaction (SCOPA is aware of value of function),

- Director General: 62,2\% positive reaction (Director General is ignorant - a negative factor),

- Management in the department: $84,2 \%$ positive reaction (management is ignorant - a very negative factor),

- General staff of national government departments: $84,2 \%$ positive reaction (general staff are ignorant - also a very negative factor);

- Confusion of the internal auditing function with the previous "inspectorate" function ( $84,2 \%$ supported the statement). The internal auditing function will have to address this perception.

- The internal auditing function is seen to overlap with the external auditing function (Auditor General). This statement enjoyed the support of $78,9 \%$ of respondents. Once again, it indicates the widely held misconceptions on the utilitarian value of the internal auditing function.

- Lack of resources (funds) for the efficient operation of the internal auditing function. This statement on the lack of resources was supported by $68,4 \%$ of the respondents.

- Management does not always demonstrate an understanding of the relevant requirements of the Public Finance Management Act in respect of the practising of the internal auditing function in national government departments. It is a great source of concern that $68,40 \%$ of the respondents supported this statement, particularly if it is considered that the progress and utilisation of the internal auditing function is largely in the hands of management;

- The head of internal audit does not have direct access to the accounting officer. This statement received a negative reaction from 
$57,9 \%$ of the respondents. It is heartening to know that respondents experience no problems in obtaining access to the accounting officer in the operation of the internal auditing function.

- It is difficult to fulfil the responsibility of the internal auditing function in the national government departments to evaluate systems of financial and risk management and internal control, and to make recommendations for the improvement thereof because the systems is not in place everywhere. A total of $57,9 \%$ of the respondents supported this statement.

- The financial information systems in the public sector are governmentcontrolled systems and are not modified to facilitate the requirements of the Public Finance Management Act. Financial information systems in the public sector should have be adapted to fulfil the requirements of the Public Finance Management Act. A large majority of $78,9 \%$ of the respondents supported this statement.

Several of the factors stated above that ultimately prevent management from understanding and utilising the full value of the internal auditing function as set out in the official description thereof. It is a matter of concern that heads of internal audit are of the opinion that internal auditors in the public sector are generally not aware of the full extent of the value of the internal auditing function. It is difficult to understand why it should take such internal auditors so long to get to a level at which they in practicing their profession, are also marketers thereof. It is obvious that urgent reflection is required on the cultivation of a professional ethos for the practicing of the internal auditing function by a large spectrum of internal auditors in the public sector.

Some disturbing information that emanates from the discussion above is the negative perception that respondents have of the lack of knowledge of key role players in the operation of an internal auditing function in the public sector. It is indeed disturbing to learn that the following key role players are not merely ignorant about the internal auditing function, but also that the lack of knowledge impedes the operation of the internal auditing function:

- Political heads of the departments (Minister)

- Directors General

- Managers of departments

- General staff in national government departments.

Only the Standing Committee on Public Accounts (SCOPA) is considered to comprise experts on the nature and value of the internal auditing function 
in the public sector. It is very promising, because such an influential body as SCOPA should be the initiator, together with the audit committee, of new initiatives to impress upon management the value of the internal auditing function. If the value is realised, more directed attempts could be made to consider more closely the specific needs of internal auditing departments.

\subsubsection{Audit staff issues as an obstacle}

For an internal auditing department to render the best quality of internal auditing service to clients, it is essential that the internal auditors, who are involved in the internal auditing assignment, should jointly have the required professional knowledge, skills and expertise. Briefly, they should be professionally proficient.

The statements that are relevant to this matter in the research, were supported by an average of $74,6 \%$ of the respondents. With this overwhelming response, they in fact agreed that competent and professionally proficient internal audit staff are vital for the successful operation of an internal auditing function. As already mentioned, the guidelines on the qualities of professionally proficient internal audit staff are set out in General Standard 200 "Professional Proficiency" of the Standards for the Professional Practice of Internal Auditing of the Institute of Internal Auditors Inc (1998:17).

The following factors served as the basis for the statements used to poll opinions on staff issues as a possible obstacle in the operation of an internal auditing function in the public sector:

- A lack of trained personnel to perform all auditing assignments such as operational audits, performance audits, computer audits, contract audits and special investigations (such as fraud). The statement was supported by $84,2 \%$ of the respondents.

- In the past, unwanted personnel in other departments were "dumped" in the internal auditing departments. A total of $73,7 \%$ of the respondents supported the statement.

- A lack of appropriate academic training programmes at universities and technikons for internal auditors in the public sector. A total of $78,9 \%$ of the respondents supported the statement;

- A lack of experienced internal auditors in national government departments to implement the requirements of the Exchequer Act. The statement enjoyed the support of $73,7 \%$ of the respondents.

- A lack of proper training facilities for internal auditors in the public sector to provide the resources to execute the requirements of the 
Exchequer Act. The statement was supported by $63,2 \%$ of the respondents.

- A lack of properly trained personnel. Altogether $73,7 \%$ of the respondents supported the statement.

To the above should be added the ignorance of the internal auditors (in general in the public sector) about the value of the internal auditing function for a particular national government department. This matter was highlighted in the preceding discussion and was supported by $78,0 \%$ of the respondents.

Of the four categories issues discussed above, the last category, namely "audit staff issues as an obstacle" is the matter of greatest concern in the operation of the internal auditing function in the public sector. The category namely "Lack of a professional relationship of internal auditors" which is discussed immediately hereafter, could be seen as a contributory factor to the current situation.

Without professionally proficient internal audit staff an internal audit department in a national government department cannot render a professional internal auditing service of the highest quality. An internal auditing service of the highest quality is one that is affordable to its clients, consistently complies with the standards of professional practice of internal auditing and has a positive impact on the final results of a national government department. An internal auditing function that does not pursue this goal with great earnestness, exposes itself to outsourcing.

\subsubsection{Lack of professional relationship of internal auditors}

As mentioned above, a group of professional persons, that are members of a professional body will have greater understanding of and dedication to for the maintenance of professional standards in service rendering as well as respect for ethical norms, than a group of non-professional persons that render the same service. Employers in general are very aware of and have great respect for the level of service rendering and the respect for standards and ethical norms that professional persons display in the execution of their task. Therefore internal auditing service of the highest quality should be a self-evident goal of professional internal auditors.

A lack of professional relationship of internal auditors was so significant that it was used as a separate category in the questionnaire. The purpose of the statements in this category in the questionnaire was to determine the level of awareness potential in the internal audit departments and in the national government departments of the value and benefits of membership 
of The Institute of Internal Auditors. The statements were supported by the following findings:

- Internal auditors are not being obliged to be members of a professional association. A total of $63,2 \%$ agreed that this situation prevailed in their internal audit departments.

- Too few internal auditors in the public sector are members of The Institute of Internal Auditors in South Africa. The positive response of $63,2 \%$ is very encouraging as it indicates that heads of internal audit are already aware of the value of professional membership.

- Some national government departments are not prepared to pay internal auditors' membership fees of IIA (SA). Only $42,1 \%$ of national government departments do pay the professional membershipfee on behalf of their audit staff. Although this finding is discouraging, it is an indication of the awareness of the value of professional membership of staff members;

- The highest professional qualification for internal auditors, namely Certified Internal Auditor (CIA), is completely unknown in the public sector. A total of $78,91 \%$ o of heads of internal audit departments agreed with this situation. Although heads of internal audit departments could be expected to inform their accounting officer, with the support of the audit committee, about the value of a CIA qualification the promotion of the CIA qualification could probably be better achieved by a joint effort of the head of internal audit department and representatives of the IIA (SA).

A greater awareness of the value of professional membership of internal auditors should be promoted by the internal auditors, the internal audit departments and the national government departments. The value of the highest professional qualification for internal auditors, viz, Certified Internal Auditor (CIA), should be promoted in the public sector. In the promotion of professional membership for internal auditors, as with all the categories mentioned above, the audit committee has a special role to fulfil.

\subsubsection{The value of the audit committee}

As mentioned in the preceding section, the audit committee is a relatively new concept in the public sector in South Africa. The audit committee that has been in existence the longest, was established no more than three years ago. With a few exceptions, all national government departments have audit committees at their disposal. The place and reporting line of an audit committee in a typical national government department is illustrated in the organogram. 
Audit committees have a special role to fulfil in the national government departments, specifically in respect of the addressing of problems experienced by internal audit departments in operating the internal auditing function. Therefore the audit committees should with great care approach and address the research findings in each of the various categories.

Because audit committees are relatively new in the public sector, the purpose of the statements in this category in the questionnaire was to determine the experience of the initial activities of the audit committee in the operation of the internal auditing function. The statements, which are based on the following factors, could have been influenced by the fact that the audit committees had been established relatively recently.

- Some internal audit departments initially had to manage without audit committees to support their independence and objectivity. This was perceived as a constraint on the independence and objectivity of the internal audit department by $68,4 \%$ of the respondents.

- The audit committee was not independent as it was operated by internal members. This statement enjoyed the support of $57,9 \%$ of the respondents. A situation in which the audit committee is operated by internal members is a serious threat to the effectiveness expected of the committee.

In the discussion of the category "Independence of the internal auditor" above, it was pointed out that the audit committee has a significant role to fulfil in ensuring that the independence of internal auditing in the public sector, with reference to the definition of internal auditing and internal audit standards, remains the unfettered critical element in the operation of the internal auditing function. The audit committee is a relatively new 
concept in the public sector. Based on the outstanding and growing role of the audit committee, particularly in the environment of corporate governance in the private sector, there is justification to expect the audit committee in the public sector to address and find answers to the problems revealed by the research findings in the different categories above.

The value of the audit committee, is summarised by the two following remarks by respondents:

1. "Even though audit committees meet the requirements of the Public Finance Management Act most of them are dominated by internal audit committee members since outside members are not always familiar with the business of National Government Departments".

2. "Directors General must not serve on audit committees; they should only be there on invitation. The audit committee must have greater impact. It must be more aggressive and show teeth - not just fulfil a gentleman's role."

In respect of the first remark, such a situation could arise, although Section 77 of the Public Finance Management Act (Act 1 of 1999 as amended) provides room for such a situation with the provision "(ii) the majority may not be persons in the employment of the department, except with the approval of the relevant treasury ...", because members of other national government departments could serve on an audit committee. In such a case they could dominate the audit committee with their inside knowledge.

The following comment is made in response to the second remark:

- It is not desirable for a Director General to serve on an audit committee;

- If an audit committee wishes to have impact, it should take decisive action.

\subsubsection{Closing thoughts on obstacles in the operation of an internal auditing function in the South African public sector}

Various research findings were discussed under the various categories above. There, can be no doubt that an excellent internal auditing function that is affordable, continually complies with the Standards for the Professional Practice of Internal Auditing (and by implication, those that are defined in the definition of internal auditing) and makes a positive impact on the bottom line of an organisation, must be the goal of an internal audit department, also in the public sector.

A great number of stumbling blocks that impede the operation of an internal auditing function, particularly in the national government 
departments, were identified by heads of internal audit in this research. Heads of internal audit and audit committees in particular have a significant role to fulfil in addressing the stumbling blocks identified in the research findings.

Nineteen national government departments were involved in this research project. The research findings have a bearing, to a greater or a lesser extent, on all nineteen of these departments. Therefore the research findings may also be relevant for the other thirteen national government departments that were not involved in the research.

A joint, meaningful and cost-effective marketing action should have to be launched by all national government departments to address the stumbling blocks in the operation of the internal auditing function. The goal should be to bring to public sector, and to the attention of key role players such as the Standing Committee on Public Accounts (SCOPA) and the political head of department (minister), the value of a high quality internal auditing function. The stumbling blocks in the way of the operation of the internal auditing function revealed by this research could also be publicised in the action. The appropriate body to launch the marketing action at SCOPA and with the Minister is the audit committee. All chairmen of audit committees in the public sector will have to appoint a small committee from among their members for this purpose. The marketing document of the internal auditing function should be in the form of an INTERNAL AUDIT MISSION STATEMENT which specifies the main elements of a high quality internal auditing function. The further advantage of a mission statement is that it is not only client-directed, but also promotes understanding within the internal audit department and the national government department responsible for the internal auditing function. This may also serve as a goal for a model internal auditing function in the broad public sector.

An example of an INTERNAL AUDIT MISSION STATEMENT of a entity, which could also be used in the public sector, is presented below. 


\section{Example of a mission statement for an internal audit \\ department in a public entity}

TO PROVIDE A WORLD-CLASS INTERNAL AUDIT SERVICE TO OUR CLIENTS THAT IS PREFERRED AND COST-EFFECTIVE

\section{ANALYSIS OF OUR MISSION:}

\begin{tabular}{|c|c|}
\hline To provide & $\begin{array}{l}\text { Not because it is a statutory requirement but because it } \\
\text { is our chosen profession and we like doing what we are } \\
\text { doing }\end{array}$ \\
\hline A world class & $\begin{array}{l}\text { - Affordable to our clients } \\
\text { - Always achieving the Standards for the Professional } \\
\text { Practice of Internal Auditing } \\
\text { With a definitive (positive) impact on the XYZ } \\
\text { public entity's bottom line }\end{array}$ \\
\hline IA service & $\begin{array}{l}\text { - CONSULTING AND PROVIDING ASSURANCE } \\
\text { to our clients on matters relating to control, risk } \\
\text { management and corporate governance } \\
\text { OUR PRODUCTS: } \\
\text { Process audits; IT audits; systems in development } \\
\text { audits; after-implementation audits; performance } \\
\text { audits; forensic audits; environment audits. }\end{array}$ \\
\hline To our clients & $\begin{array}{l}\text { PRIMARY } \\
\text { Board of directors (Audit committee) } \\
\text { Top management } \\
\text { SECONDARY: } \\
\text { All other levels of management } \\
\text { Regulators } \\
\text { External auditors } \\
\text { Clients } \\
\text { All staff } \\
\text { Unions }\end{array}$ \\
\hline That is preferred & $\begin{array}{l}\text { We should be preferred to our competition, namely } \\
\text { the external auditors, external business consultants } \\
\text { and other internal reviewers }\end{array}$ \\
\hline And cost-effective & $\begin{array}{l}\text { e We should measure what our service costs and } \\
\text { ensure that the return exceeds the cost }\end{array}$ \\
\hline
\end{tabular}




\section{$5 \quad$ Conclusions and recommendations}

The internal auditing function is already well established in countries abroad. The United States and various other countries have played a major part in broadening the role of the internal auditor in the government environment

The scope of the services offered by the internal auditing function has expanded to such an extent since its inception in a professional context in 1941 that in 1999 The Institute of Internal Auditors Inc was obliged to accept a new definition of internal auditing. This definition, as well as the internal auditing standards of the Institute, served as criteria in terms of which the various audit aspects of the establishment and operation of the internal auditing function in the public sector were assessed.

The establishment of the internal auditing function in the public sector in South Africa has not only had an interesting run, but has also been given new status by the Public Finance Management Act (Act 1 of 1999 as amended) and the Treasury Regulations (Regulation Gazette No 6822 dated 31 May 2000). Although the statutory provisions regarding the functioning of the audit committee and the internal auditing function are very limited in scope, the provisions have in fact given reasonable momentum to it.

This research focussed on two matters regarding internal auditing in the public sector, viz. "obstacles in the establishment of the internal auditing function" and "obstacles in operating the internal auditing function" respectively. Statements were formulated in the research questionnaire, based on factors which became evident from discussions at the Audit Forum of the Institute for Public Finance and Auditing and from personal discussions with a some heads of internal audit. The questionnaire was forwarded to 32 heads of internal audit. A total of 21 questionnaires were returned, of which two indicated that the internal auditing function was outsourced. The remaining 19 questionnaires were used in the research.

The fact that a few heads of internal audit departments indicated beforehand that their co-operation was threatened by the eventual disclosure of the research findings might have affected the research findings and recommendations.

The following findings and recommendations are deduced from the research information: 


\subsection{Obstacles in the establishment of the internal auditing function}

\section{- Independence of the internal auditor}

Stumbling blocks identified under the category independence, were the newness (strangeness) of the internal auditing function, initial lower level of reporting than the Director General and the establishing of audit committees which began at a late stage.

\section{- Poor image of the internal auditing function}

It was found that there was still a reasonably widely held view that internal auditing in the public sector is identified with the earlier "inspectorate" function, with the internal auditing function being revealed as overlapping with the external auditing function (Auditor General) and the function being prejudiced by the head of internal audit being located at too low a post level. It is recommended that the post level should at least be that of director or chief director.

- Inability of management to exploit the usefulness of the internal auditing function - the cardinal findings:

- Ignorance of the nature and value of the internal auditing function with key role players such as the political head of national government department (minister), Director General, management in the department and general staff of national government departments.

- The consulting value of the internal auditing function in the public sector is not publicised sufficiently.

\section{- Audit staff issues as an obstacle}

- There are few experienced internal auditors in national government departments available to implement the requirements of the Exchequer Act; there is lack of proper training facilities for internal auditors in the public sector; there is a lack of appropriate training programmes for internal auditors in the public sector at universities and technikons; and, lastly, some unwanted personnel in other departments were "dumped" in internal auditing.

- This comprises a critical element of the internal auditing function and should receive urgent attention.

- Lack of professional relationship of internal auditors 
Internal auditors not being obliged to be members of a professional association; too few internal auditors in the public sector are members of The Institute of Internal Auditors; some national government departments are not prepared to pay professional membership fees; and the highest professional qualification of internal auditors, namely Certified Internal Auditor (CIA), is completely unknown in the public sector.

\section{- The value of the audit committee not fully exploited}

The audit committee should address all the above matters. The audit committee was not able to do this, because it was still in the process of establishing itself.

\subsection{Obstacles in the operation of the internal auditing function}

The findings and recommendations have a large measure of agreement with the preceding one, therefore only the following are highlighted as being the most important:

\section{- Independence of the internal auditor}

The independence of the internal auditor in the operation of the internal auditing function in the public sector is not a foregone conclusion. it deserves urgent attention, also from the audit committee, because independence, with reference to the new definition of internal auditing and internal auditing standards is a critical element in the operation of an internal auditing function.

\section{- Image of the internal auditing function}

This matter depends largely on the professional manner in which the internal auditor fulfils the internal auditing function. Will the internal auditor be able to add value and improve the department's operations? If this is the case, the outlook for the function should be positive.

- Ability of management to exploit the usefulness of the internal auditing function

The internal auditing function should provide assurance to management on matters relating to control, risk management and corporate governance. Factors that impede this function in the public sector are, amongst other things, the fact that internal auditors in the public sector are ignorant of the value they could add to a department. On the other hand, ignorance about the nature 
and value of the internal auditing function is considered to be a serious stumbling block in the full utilisation by top management, especially the following key role players:

Political head of the national government department,

Director General and management in the Department.

\section{- Audit staff issues as an obstacle}

All the audit staff issues highlighted deserve urgent attention. Without professionally proficient internal auditing staff an internal audit department in a national government department can not render an internal auditing service of the highest quality. This is yet another crucial element in the operation of an internal auditing function.

\section{- Lack of professional relationship of internal auditors}

A professional internal auditing service of the highest quality can only be promoted if a greater awareness of the value of the professional membership of internal auditors is cultivated in internal auditors, internal audit departments and national government departments.

\section{- Value of the audit committee}

The audit committee is a relatively new committee in the public sector in South Africa. Audit committees that are already in operation are already adding value to certain departments. It would benefit audit committees in the public sector to approach and address with circumspection the research findings that are shown under the various categories in this research.

In the preceding closing discussion, an internal audit mission statement of a public entity was presented as a model, which could be used in a joint marketing attempt by internal audit departments and based on the research findings of this project. Various internal audit departments experience various problems of which a large number are addressed in this research.

Chairmen of all audit committees in the national government departments could, with the assistance of a typical document like the internal audit mission statement, market in a joint action the value of internal audit function of high quality for the public sector (national and provincial) with the key role players such as the Standing Committee on Public Accounts (SCOPA) and the political head of department. The stumbling blocks in the 
path of the operating of an internal auditing function, identified in this research, could also be highlighted at that opportunity.

The exploitation of the value of joint efforts of audit committees in the South African public sector is an area that requires further research.

Finally, it is hoped that the research findings in this research project will be of benefit, firstly to developing countries that envisage bringing about an internal auditing function in the public sector and, secondly, to the public sector in South Africa. If that should occur, the two primary objectives of this research project would have been achieved.

\section{Bibliography}

Flesher, D.L. 1996. Internal Auditing Standards and Practices, The Institute of Internal Auditors, Altemonte Springs, Florida.

Hald, A.E. 1944. The Functions of the Internal Auditor, Internal Auditing philosophy and practice, edited by Charles J. Fue, Brock and Wallston, Stamford, Connecticut.

Republic of South Africa. 1975. Exchequer Act (Act 66 of 1975 augmented by way of Government Gazette No. 5791, dated 1 November 1996, Republic of South Africa.

Republic of South Africa. 1992. Reporting by Public Act (Act 93 of 1992) supported by Regulations Concerning Public Entities (in Government Gazette No. 5076, dated 7 May 1993), Republic of South Africa.

Republic of South Africa. 1995. Auditor General Act (Act 12 of 1995), Republic of South Africa.

Republic of South Africa. 1999. Public Finance Management Act(Act 1 of 1999 as amended by the Public Finance Management Amendment Act (Act 29 of 1999)), Republic of South Africa.

Republic of South Africa. 1999. Public Finance Management Act, 1999 Treasury Regulations (in Regulation Gazette No 6822, dated 31 May 2000), Republic of South Africa.

Sawyer, L.B., Dittenhofer, M.A. \& Scheiner, J.H. 1996. Sawyer's Internal Auditing, The Institute of Internal Auditors, Altermonte Springs, Florida. 
Standards for the Professional Practice of Internal Auditing. 1998. The Institute of Internal Auditors, Altermonte Springs, Florida.

The Institute of Directors in Southern Africa. 1994. The King Report on Corporate Governance, Parklands, The Institute of Directors in Southern Africa.

Update, 1999. The Internal Audit Profession - Redefined, Internal Auditor, August 1999, Vol. LVI, No. IV, p.11. 